\title{
Comorbidities of Inflammatory Arthropathies in the Art of Diego Velázquez
}

DOLORES RAMOS-BELLO, MD; CARLOS ABUD-MENDOZA, MD, Regional Unit of Rheumatology and Osteoporosis, Central Hospital and Faculty of Medicine, Universidad Autónoma de San Luis Potosí, San Luis Potosí, México. Address correspondence to Dr. C. Abud-Mendoza, Palmira 600-606, col. Villas del Pedregal, San Luis Potosí, México. E-mail: c_abud@hotmail.com. J Rheumatol 2017;44:1878-9; doi:10.3899/jrheum.170818

The relationsh^ip between the rheumatologic diseases, rheumatoid arthritis (RA) and osteoarthritis (OA), is based on common physiopathogenic mechanisms and correlations of their mutual presentation ${ }^{1,2}$. We discuss the historical association between these 2 conditions through the analysis of European artwork from as early as the 15 th century.

Diego Rodríguez de Silva y Velázquez (1599-1660) was one of the most important painters of the Spanish Golden Age, and the leading artist in the court of King Philip IV. He was an individualistic artist of the contemporary Baroque period and was important as a portrait artist.
In addition to numerous renditions of scenes of historical and cultural significance, in 1618 Velázquez painted one of his most notable compositions of his early period in Madrid, Old Woman Frying Eggs (oil on canvas, $100.5 \times 119.5 \mathrm{~cm}$; Figure 1), now held at the National Gallery of Scotland in Edinburgh. The presence of trapeziometacarpal OA in both hands of the old woman with more advanced rizarthrosis on the left hand was described in $1992^{3}$. We discuss the subject of the painting with a diagnostic eye and suggest that the woman also had RA. Our diagnosis of the woman in this historical painting

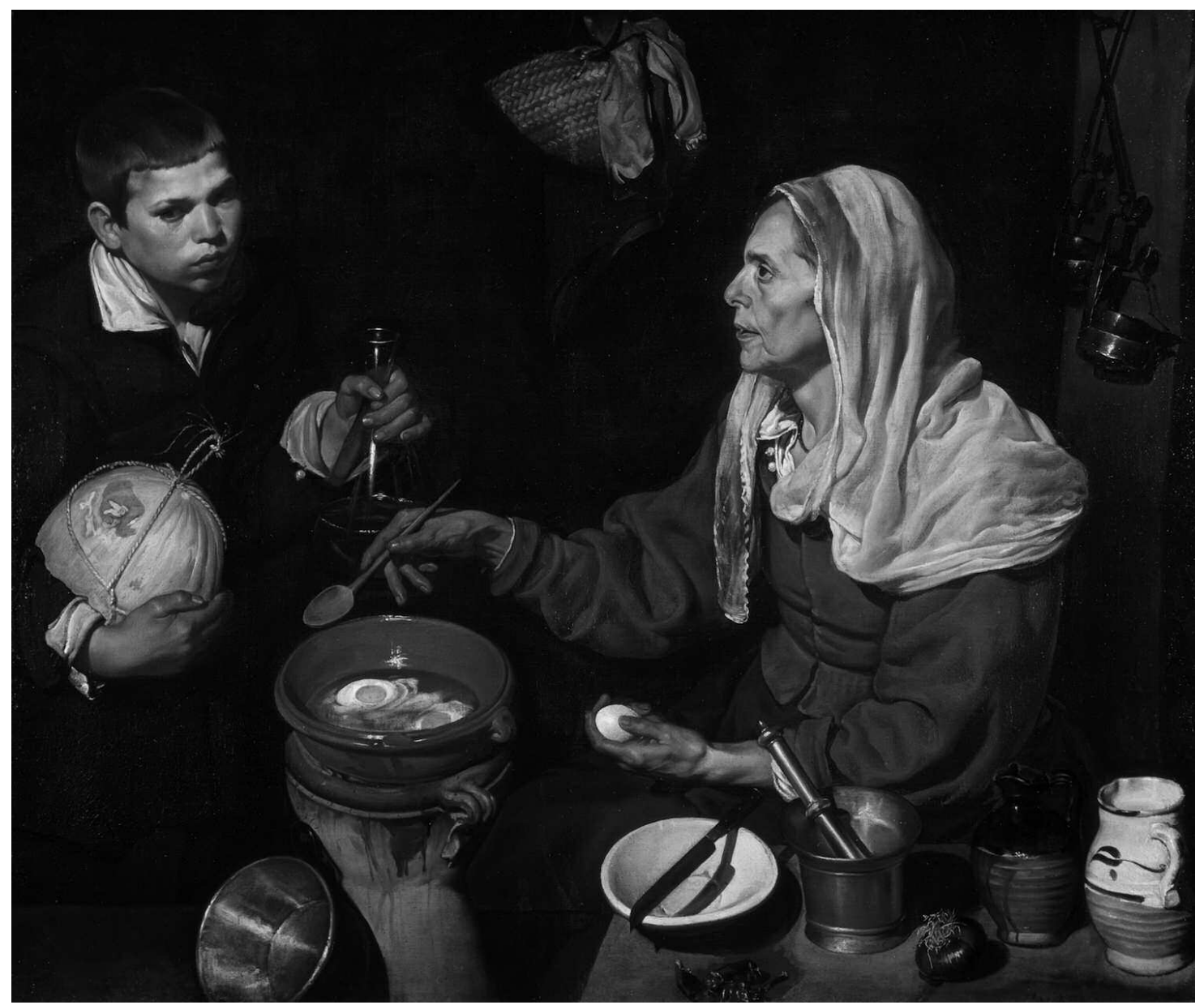

Figure 1. Diego Velázquez (1599-1660). An Old Woman Cooking Eggs, 1618. Oil on canvas, $100.5 \times 119.5$ cm. Collection: Scottish National Gallery. Purchased with the aid of the Art Fund and a Treasury Grant 1955. Republished with permission. 
supports a longtime and persistent association between these 2 disorders.

Looking at the woman's features, we focus our attention on the anatomic disruptions of the right hand, holding a wooden spoon. The hand presents a prominent second metacarpophalangeal (MCP) joint and possible subluxation of the MCP joints associated with ulnar deviation of the third and fourth fingers, suggestive of an RA-forced functional alteration, indicated by the way she holds the spoon.

Historically, the medical description of RA was attributed to the French physician Dr. Augustin Jacob Landré-Beauvais (1772-1840) in 1800 under the name of aesthetic gout and renamed properly as RA by British rheumatologist Sir Alfred Baring Garrod in 1859. Its presence was recognized in other artwork such as the Jan van Eyck portrait of John IV, Duke of Brabant, dated 1441, and paintings by Jacob Jordaens $(1593-1678)^{4}$. Velázquez's portfolio suggests the existence of RA prior to the classical diagnostic paper of
Landré-Beauvais ${ }^{5}$. Notably, the described association between RA and OA demands a new look at these retroactive diagnoses of OA that could also include $\mathrm{RA}^{4}$.

\section{REFERENCES}

1. Figueiredo CP, Simon D, Englbrecht M, Haschka J, Kleyer A, Bayat $\mathrm{S}$, et al. Quantification and impact of secondary osteoarthritis in patients with anti-citrullinated protein antibody-positive rheumatoid arthritis. Arthritis Rheumatol 2016;68:2114-21.

2. Kontny E, Zielińska A, Księżopolska-Orłowska K, Głuszko P. Secretory activity of subcutaneous abdominal adipose tissue in male patients with rheumatoid arthritis and osteoarthritis - association with clinical and laboratory data. Reumatologia 2016;54:227-35.

3. Castillo-Ojugas A. Trapeziometacarpal osteoarthrosis in a painting by Diego Velazquez. Arthritis Rheum 1991;34:127-8.

4. Yeap SS. Rheumatoid arthritis in paintings: a tale of two origins. Int J Rheum Dis 2009;12:343-7.

5. Dequeker J, Rico H. Rheumatoid arthritis-like deformities in an early 16th-century painting of the Flemish-Dutch school. JAMA 1992;268:249-51 